\title{
Reflections on Music Performance and Dancing in a Roman Mosaic Found on the Aventine
}

\section{Aventine'de Bulunan Bir Roma Mozaiğinde Müzik Performansı ve Dans Üzerine Düşünceler}

\author{
Luz NEIRA - Isabel RODRÍGUEZ*
}

(Received 12 January 2021, accepted after revision 12 August 2021)

\begin{abstract}
This paper focuses on a figurative scene with musicians and dancers in one of the mosaics found in the grounds of Santa Sabina garden on the Aventine, currently preserved in the Vatican Museums. This representation has been the object of different interpretations and chronological analysis within the context of mime or, more recently, that of a banquet.

This contribution delves into whether, judging by the analysis of the iconography and literary sources, these are images that respond to a stereotyped repertoire or they reflect customary practices of that time. Finally, we will also reflect upon to what extent the representation of the protagonists of the event is reliable.

To address these questions, it has been necessary to date the mosaic to the beginning of the third century AD, establishing this chronology by comparing the geometric pattern of the mosaic with another found nearby, while also considering the revealing testimonies of contemporary authors, such as Clement of Alexandria.
\end{abstract}

Keywords: Tibicines, saltatrices, saltatores, dwarf, convivium, literary sources, Clement of Alexandria.

\section{Öz}

Bu makale, Aventine'deki Santa Sabina bahçesinin arazisinde bulunan ve şu anda Vatikan Müzeleri'nde korunan mozaiklerden birinde betimlenen müzisyenler ve dansçıların olduğu figüratif bir sahneye odaklanmaktadır. Bu temsil, mim veya daha yakın zamanda bir ziyafet bağlamında farkll yorumların ve kronolojik analizlerin konusu olmuştur.

Bu katkl, ikonografi ve edebi kaynakların analizine göre, bunların kalıplaşmış bir repertuvara yanıt veren görüntüler mi, yoksa o zamanın geleneksel uygulamalarını mı yansıttığını araştırmaktadır. Son olarak, olayın kahramanlarının temsilinin ne kadar güvenilir olduğu üzerinde de durulacaktır.

Bu soruları ele almak için, mozaiğin geometrik desenini yakınlarda bulunan bir başka mozaik ile karşılaştırarak kronoloji oluşturulacak ve aynı zamanda İskenderiyeli Clement gibi çağdaşı yazarların açıklayıcı tanıklıklarını da göz önünde bulundurarak mozaiğin İS üçüncü yüzyllın başlarına tarihlendirilmesi gerekmektedir.

Anahtar Kelimeler: Tibisinler, saltatrisler, saltatores, cüce, convivium, edebi kaynaklar, İskenderiyeli Clement.

\footnotetext{
* Luz Neira Jiménez, Universidad Carlos III de Madrid, Getafe, Madrid, Spain. (D) https://orcid.org/0000-0002-2421-6792. E-mail: Ineira@hum.uc3m.es Isabel Rodríguez, Universidad Complutense de Madrid, Spain. (D) https://orcid.org/0000-0002-6671-8213. E-mail: mirodrig@ucm.es This article is the result of the investigations carried out in the Project EPUC3M16 "La idea de frontera desde la Historia, la Geografía y el Arte. Ref. 2020/00552/001
} 
While breaking the news about the discovery of certain mosaics in the grounds of Santa Sabina on the Aventine in 1711, during the pontificate of Clement XI, Lanciani refers to previous information present in the Eton Collection and the Cod. Corsini ${ }^{1}$ : he mentions some musive panels preserved in the Vatican Museums (Lanciani 1895: 189). According to the famous Italian archaeologist, there are four emblemata of venationes and one scene of "revelry", in which several individuals seem to celebrate and dance to the sound of music. These pavements were later included in other publications (Nogara 1910: $7 \mathrm{pl}$. IX fig. 5; Ashby 1914: 40 no. 38) and after several decades, in Blake's works on the mosaics of Rome and its vicinity (Blake 1936: 174-175; 1940: 84, 115-117 pl. 30 fig. 6 pl. 31 fig. 1-4). The American scholar named the scene of interest in our article "Vaudeville Performers" and mentioned the different hypotheses about the chronology of the domus found under Santa Sabina, citing Muñoz, author of three works on the basilica (Muñoz 1914: 332- 334 figs. 1-4; 1919: 31-32 pl. XII; 1924: 36-37). He was the first author to propose a date between the second and third centuries and, later, its adscription to the third century. For this reason, Blake did not openly include the mosaics of the Aventine domus in her extensive work on mosaics of the second century (Blake 1936: 67-214), but in her work on those of the Late Empire (Blake 1940: 115- 117).

In order to propose a date for these mosaics, it is critical to analyse those with venationes: in the larger rectangular panel there is a fight between an elephant and a bull, and the capture of a lion at the hands of a venator riding on a dromedary; in the second panel, a confrontation between a bull and a bear; in the third panel, a horseman chasing a bull; in the fourth panel, two standing venatores facing a bear (Berthier 1910: 19-20; Nogara 1910: 6-7; Blake 1940: 115-116. pl. 31, 1-4). These panels include animals that have been well documented since Antiquity, especially in the arena of amphitheatres, such as bulls, lions and bears - and even the elephant, whose representation fighting against a bull also appeared in a coin issued by Gordian III to commemorate the Ludi Saeculares (Nash 1968: 269 fig. 317), and in another by Philip the Arab. This was the argument used by Blake to date the musive scene to the time of these rulers or to the period that goes between Gordian and Constantine (Blake 1940: 116). However, Pliny (Plin. nat. 8.19) already referred to the confrontation of an elephant and a bull in the arena in $75 \mathrm{BC}$, being aedilis Lucullus. Martial also alluded to this type of animal fights (Spect. 19.2), as was stated many years ago (Blázquez et al. 1990: 167-169 note 32).

In addition, both Muñoz and Blake reported that, among the musive finds from the domus on the Aventine, there was a black and white pavement with a geometric pattern, based on "undulating lines as white ribbons meeting and parting on a black ground in such a way as to leave spaces roughly circular, in the center of which are Maltese crosses" (Blake 1940: 84 pl. 12 fig. 3), adding that it was one of the characteristic motifs of the mosaics found in the Palace of Septimius Severus on the Palatine.

In this line of research, it should be noted that a pattern of sine waves in opposite colours - a composition of bichrome outlined pattern of opposed tangent undulating lines - is already documented in one of the pavements found in the Baths of Caracalla (Décor I: pl. 249b). This would imply a certain success of the design in Rome ${ }^{2}$, which would allow us to offer a chronology for the paving of

1 Richard Topham Drawings, which went to the Eton College Library in 1736, cf. Eton III, 50; IV, 34 38, y Cod. Cors. 137-145.

2 To be considered its representation in the Palace of Septimius Severus on the Palatine, cf. Muñoz 
the domus around the time of Caracalla, at the beginning of the third century AD - or in the following decades, in the first half of the century. ${ }^{3}$

The scene that focuses our attention "(Fig. 1)", is depicted within a rectangular area: in the middle, there is a semi-circular structure that surrounds a small table (mensa delphica), a wine amphora and, in the foreground, the figure of a dwarf facing left dressed in a short tunic while carrying a jug in his hand. This scene is flanked by two groups that bear some resemblance between them. On the left, a tibicen with the double tibia is simultaneously playing the scabellum ${ }^{4}$ with his foot, easily identified as it was represented sideways. A young saltatrix seems to be dancing -actually contorting- to that rhythm, while playing the crusmata (or crotala $)^{5}$ dressed in a very transparent tunic that reveals her buttocks. This young woman is in presence of another male who is facing her, holding sticks in his left hand. The group on the right has another tibicen-scabillarius in the same position as the one on the left, whose rhythm and pace are followed not by a couple but by a trio: the saltatrix with a transparent tunic shows her back to the viewer, revealing the movement of her glutes with the hands raised over her

Figure 1

Aventine mosaic in Vatican Museum.

Photo: Luz Neira. head and playing some crotala. She is flanked by two men who also hold sticks and perhaps, at least the one on the right, seems to be playing crotala with one of his hands.

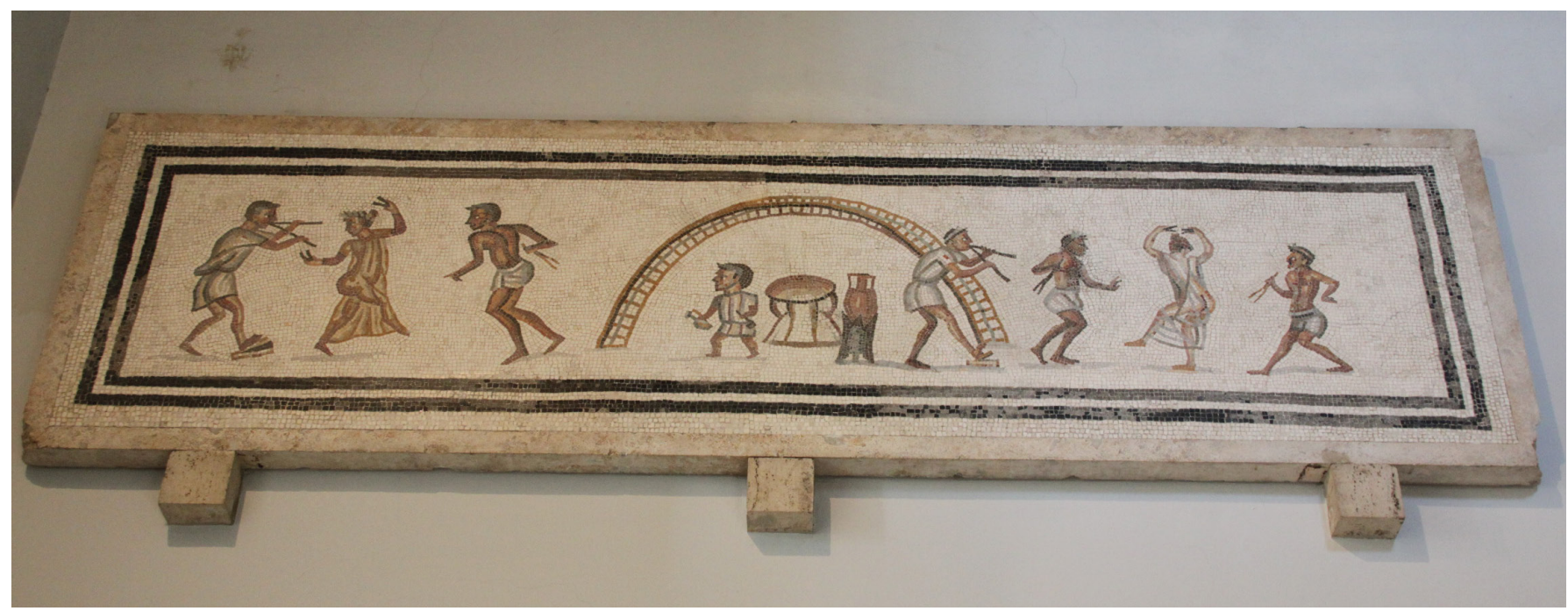

There are some interesting details of the mosaic that need to be highlighted, especially the garments worn by the two tibicines/scabillarii and the male figures that hold sticks. The first ones are dressed in short tunics, while the second ones are only covered with a cloth resembling short pants, exposing the rest of their torso, legs and feet, conveying an attitude of movement - perhaps like the cinaedi ${ }^{6}$ while dancing. Such instruments and their attire could be indicative

1924 and Blake 1940. Although not identical, it has four-petal flowers in the intervals, in Djebel Oust (Décor I: pl. 249e).

3 Wardle $(1981: 32,145)$, who includes the instruments of this scene in his thesis, assigns the mosaic to the Temple of Diana on the Aventine while dating it between the third and fourth centuries AD.

4 Cicero (Cic. Cael. 65) used the word scabillum, just like Quintilian later on (Quint. inst. 1.4.12), as did in our times (Dunbabin 2016: 86). However, Bélis (1988: 323-329), used the word scabellum, which most authors and scholars seem to follow. According the author of this paper, scabillarii were first and foremost, tibicines, although not always. In this regard, as noted by Jory (1970: 224-256), both tibicines and scabillarii joined independent collegia.

5 Latin texts refer to these instruments as crusmata. Based on their iconography, we prefer to use the word crotala from now on, not without certain doubts regarding the literary sources.

6 The cinaedi came from Egypt and other Eastern provinces of the Empire and were associated with local divinities whose ritual celebrations included percussion instruments and dances (Vesterinen 
of their origin, foreign to Rome ${ }^{7}$, and even different from that of the musicians who play the double tibia and the scabellum at the same time, who are dressed as Roman slaves.

This very same difference can be appreciated in the paintings of one of the columbaria from Villa Doria Pamphili ${ }^{8}$, with tibicines blowing the double tibia and dressed in a long tunic, while most of the cinaedi wear a cloth as short pants (Figs. 2-3). Likewise, a cinaedus in another painting from the columbarium in the Villa Doria Pamphili, that of Scribonius Menophilus ${ }^{9}$, who is dancing to the sound of sticks in his right hand, has been captured in the same position as the one represented on right side of the mosaic found on the Aventine. A cinaedi couple is also documented in the corner of the third century AD black and white mosaic that paved a tavern, the so-called Caupona of Alexander in Ostia Antica (Becatti 1961: 205-207 n⿳391 pl. CXIV) ${ }^{10}$. They are both dancing completely naked, the one on the left is a grotesque figure, endowed with an enormous phallus, just like the one that appears in the frescoes of the first columbarium, represented in the lewdest attitude before the viewers dancing to the rhythm of the double pair of sticks he carries in his hands.
Figure 2

Painting of one of the columbaria from Villa Doria Pamphili in British Museum. Photo: (B.M. No 1873,0208.1).

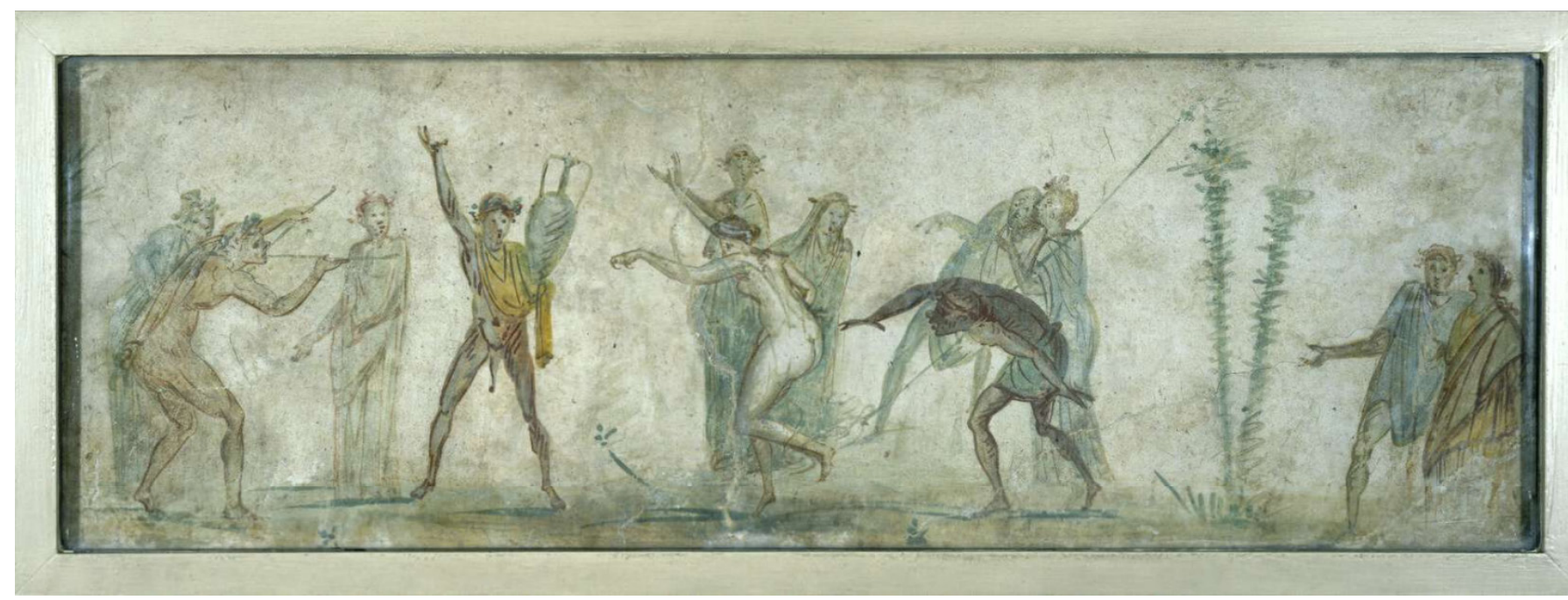

2007: 39-43). For this reason, the term cinaedi was used to designate Eastern or Egyptian dancers that apparently used to dance naked and appeared in Plautus' comedies. Later, the term was applied to any dancer, just like those who annoyed Pliny the Younger, according to a passage in his letters Cf. Plin. epist. 9.17.1-4. These cinaedi, who usually wear a characteristic cone-shaped cap (Apul. met. 8.27), are frequently represented in minor arts. Characterized by explicitly lascivious gestures and ambiguous sexuality, their representations abound, especially in the Republican period. From the Principate onwards, however, although the cinaedi shows remain as part of the entertainment for the commissatio, the fame of the pantomime manages to eclipse their daring performances. In fact, some scholars have assimilated the cinaedic dances to the so-called "Ionian dances", another type of entertainment based on the obscene movement of the body and suggestive gestures, to which Horace also refers.

7 Castaldo (2014: 318 figs. 1-3, 5-7), notes certain resemblance between the cinaedi and the renowned relief from Ariccia, in a cultic context, which she dates to the beginning of the second century AD. She also proposes an Ethiopian origin for those represented in the Aventine mosaic, which she dates to the second century AD, just like Wooton 2004: 247.

8 Partially preserved, some in Museo Nazionale Romano, others in the British Museum. Paintings are known thanks to the drawings by Ruspi made in the mid-nineteenth century and estimated to be from the first century BC, according to Dunbabin (2004: 166-168 figs. 4-7), with all the previous bibliography on the dancers with sticks. Also; King 1997: 77-80.

9 Catalli 1992: 120-125, with the same brief clothing, but wearing the characteristic cone-shaped cap that also appears in some paitings of the aforementioned columbarium, under Doria Pamphili Villa, cf. Previous note and, in ceramics, small bronzes and oil lamps, especially those found in the shrine of Demeter in Cnidus, from the second century AD, preserved in the British Museum cf. Bailey 1980: 60-62 fig. 64.

10 In this mosaic, Venus, Eros and pancratio competitores are also represented. 
Figure 3

Detail of painting of one of the columbaria from Villa Doria Pamphili in Museo Nazionale Romano. Photo: Luz Neira.

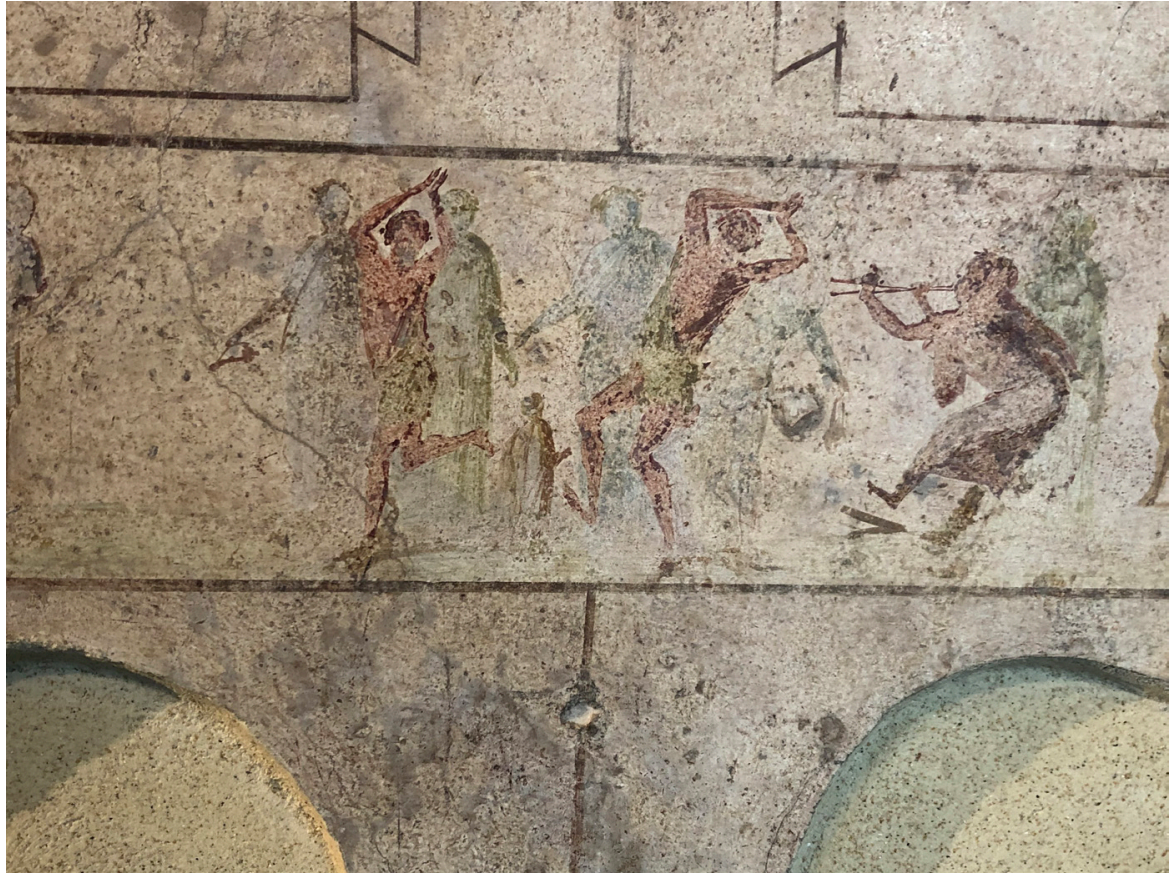

Nevertheless, the most characteristic feature in the performances of the majority of the cinaedi - and therefore of those represented in the aforementioned paintings of the columbaria, the three on the Aventine mosaic and, in particular, the cinaedus with the large phallus in the mosaic from Ostia, although less evident in the cinaedi with sticks featured alongside dwarfs and skippers in the dance outside the temple dedicated to Diana Nemorensis in the fragmentary relief of Ariccia (Lembke 1994: 97-102; Castaldo 2014: 316-317 figs 1-3) - is the depiction of a characteristic posture with the buttocks outwards that generated a quick and easy assimilation of his dance with homosexual practices (Alonso 2011: 431). The best description is found in Aulus Gellius (Gell. 6.12.5) ${ }^{11}$, who paraphrased Cornelius Scipio the African's vision about them:

"uerba sunt haec Scipionis: 'nam qui cotidie unguentatus aduersum speculum ornetur, cuius supercilia radantur, qui barba uulsa feminibusque subuulsis ambulet, qui in conuiuiis adulescentulus cum amatore cum chirodyta tunica interior accubuerit, qui non modo uinosus, sed uirosus quoque sit, eumne quisquam dubitet, quin idem fecerit, quod cinaedi facere solent?"

Scipio's words are these: "For one who daily perfumes himself and dresses before a mirror, whose eyebrows are trimmed, who walks abroad with beard plucked out and thighs made smooth, who at banquets, though a young man, has reclined in a long-sleeved tunic on the inner side of the couch with a lover, who is fond not only of wine but of men - does anyone doubt that he does what wantons commonly do?"

Thus, it is not surprising that under the name of cinaedi, three words were combined in a pejorative way: foreigner ${ }^{12}$, dancer, and effeminate (Williams 1999: 178). Returning to the mosaic of Santa Sabina, the two saltatrices show their hair in a bun, the one on the right, certainly saffron-coloured (Figs. 4-6).

11 Aulus Gellius, The Attic Nights of Aulus Gellius, Loeb Classical Library, 1927, Translation by J.C. Rolfe.

12 Regarding the foreign origin, cf. Perea 2004: 11-46. 
Both seem to evoke the description of Quintia, expert in shaking her vibrant buttocks in one of the Priapea (Priap. I.27.1-5) ${ }^{13}$, that of the puellae gaditanae by Martial (Mart. apoph. (epigr. 14) 1.41.12) ${ }^{14}$ and Juvenal (Iuv. 11.3.62) ${ }^{15}$ and that of other foreigners by Statius (Stat. silv. 1.6.67-74) ${ }^{16}$ and Suetonius (Suet. Dom. 4) ${ }^{17}$.
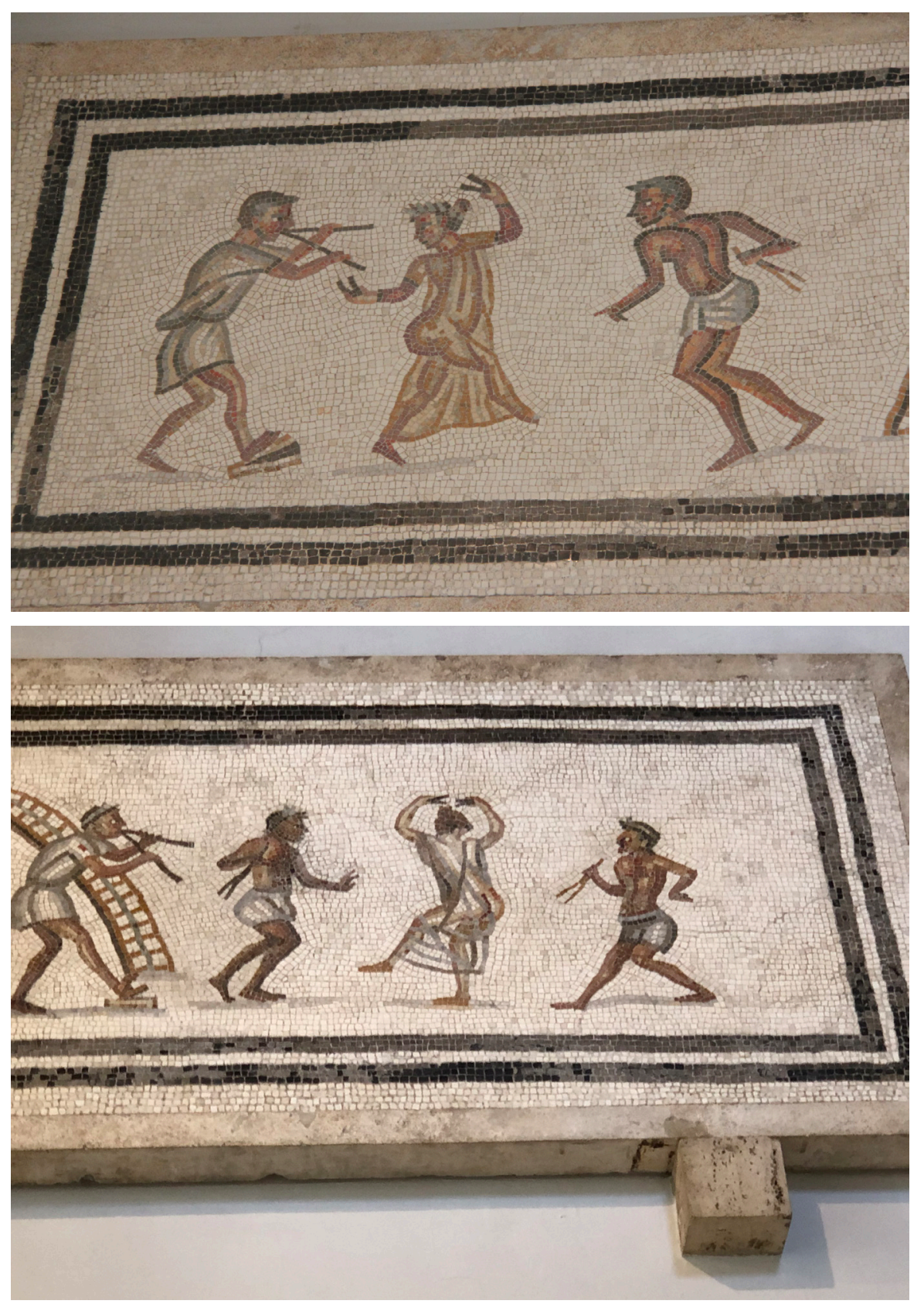

Figure 5

Detail of Aventine mosaic. Photo: Luz Neira.

13 Appendix Vergiliana. Priapea, Loeb Classical Library, 1918, Translation by H. R. Fairclough.

14 Martial, Epigrams, Volume I: Spectacles, Books 1-5, Loeb Classical Library, 1993, Translation by D. R. Shackelton Bailey.

15 Juvenal and Persius, Heinemann \& G.P. Putnam's Son, 1918, Translation by G. G. Ramsay. The puellae gaditanae were identified as prostitutes, as well as the Syrian ambubaiae, that appeared to have a certain link in Schol. Iuv. 11: id est, speras forsitan, quod incipiant saltare delicatae ac pulchrae puellae Syriae, quoniam de Syris en Afris Gades condita est.

16 Publius Papinius Statius, Silvae, Scriptorum classicorum bibliotheca Oxoniensis, 1992, Translation by E. Courtney.

17 Suetonius, Life of the Caesars, Vol II, Loeb Classical Library, 1914, Translation by J. C. Rolfe. 
Figure 6

Detail of Aventine mosaic. Photo: Luz Neira.

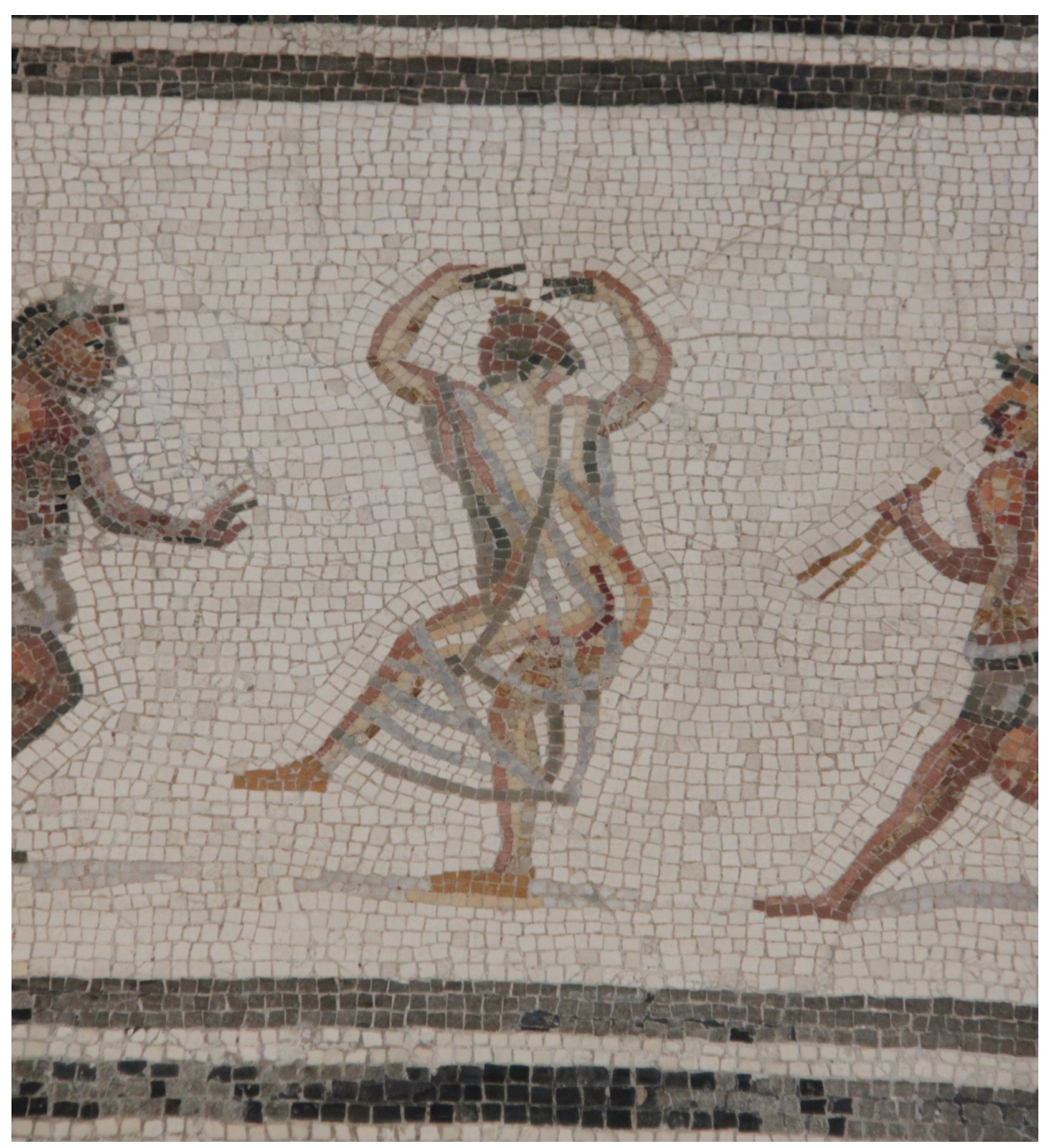

All references to the performances of the puellae offered by Carmina Priapea, Martial, Juvenal, and, most notably, Statius' mention ${ }^{18}$ of the most sensual and lascivious dancers who move to the rhythm of the crusmata (alluding to a banquet organised by Domitian during the Saturnalia with the participation of puellae from Lydia, Syria and Gades) can shed some light on the scene represented in the Aventine mosaic. Despite the supposed prominence of the musicians with different instruments, the cinaedi and the dancers, the scene in question does not include the participation of actors or mimae ${ }^{19}$, which allow us to identify it not as a sequence of mime $e^{20}$, but as the performance of one of those lascivious dances at the celebration of a great banquet.

18 According to Lindgren (2015: 136), the same celebration that Suetonius (Suet. Dom. 4) places during the ludi dedicated by the Emperor to Jupiter Capitolinus. Cf. Léveder Bernard - Calero 2015: 107-120.

19 Regarding the difference between mimae and saltatrices, and although much later see, from the end of the fourth century AD, the text by Ammianus Marcellinus (Amm.14.6.19): Postremo ad id indignitatis est ventum, ut cum peregrini ob formidatam haut ita dudum alimentorum inopiam pellerentur ab urbe praecipites, sectatoribus disciplinarum liberalium inpendio paucis sine respiratione ulla extrusis, tenerentur mimarum adseclae veri, quique id simularunt ad tempus, et tria milia saltatricum ne interpellata quidem cum choris totidemque remanerent magistris. Ammianus Marcellinus, History. Books XIV-XIX, Loeb Classical Library, 2005, Translation by J.C. Rolfe.

20 Guidobaldi 1992: fig. 18; Kondoleon 1999: fig. 5, interpret the scene as that of a mime. About the nature of these performances, Dunbabin 2004: 161-182 notes 27-28, mentions that Domitian allowed actors to play in private houses, and recalls the case of Ummidia Quadratilla, that with her own pantomime company performed both in theatres and houses, and taking into account Plutarch's text (Plut. mor. 712E), he believes that it might be a representation of a mime during a banquet "That we tend to hear more of the higher-end and cultured forms of dinner entertainment naturally reflects the prejudices of our sources. Indeed, Plutarch has one of his characters explicitly describe certain mimes - paignia - as unsuitable for a symposium, because they were so full of bomolochia and spermologia that they were not fit even for the slaves who look after their masters' shoes; but he adds that hoi polloi, even when there are women and children present, exhibit mimêmata of words and deeds that are more disruptive even than drunkenness". Cf. Dunbabin 2016: 130 fig. 5.16. 
The semi-circular structure, in a sigma shape, also contributes to this identification, typical of a banquet, as it is documented in a fragmentary parietal mosaic in Sant'Angelo in Formis (Campania) (Robotti 2005: 1171-1173 fig. 4; Neira 2011: 400) "(Fig. 7)" and in a mosaic of Thysdrus, with the members of the sodalitates at the dinner prior to the ludi (Blanchard-Lemee et al. 1995: 210 fig. 155) (Fig. 8).
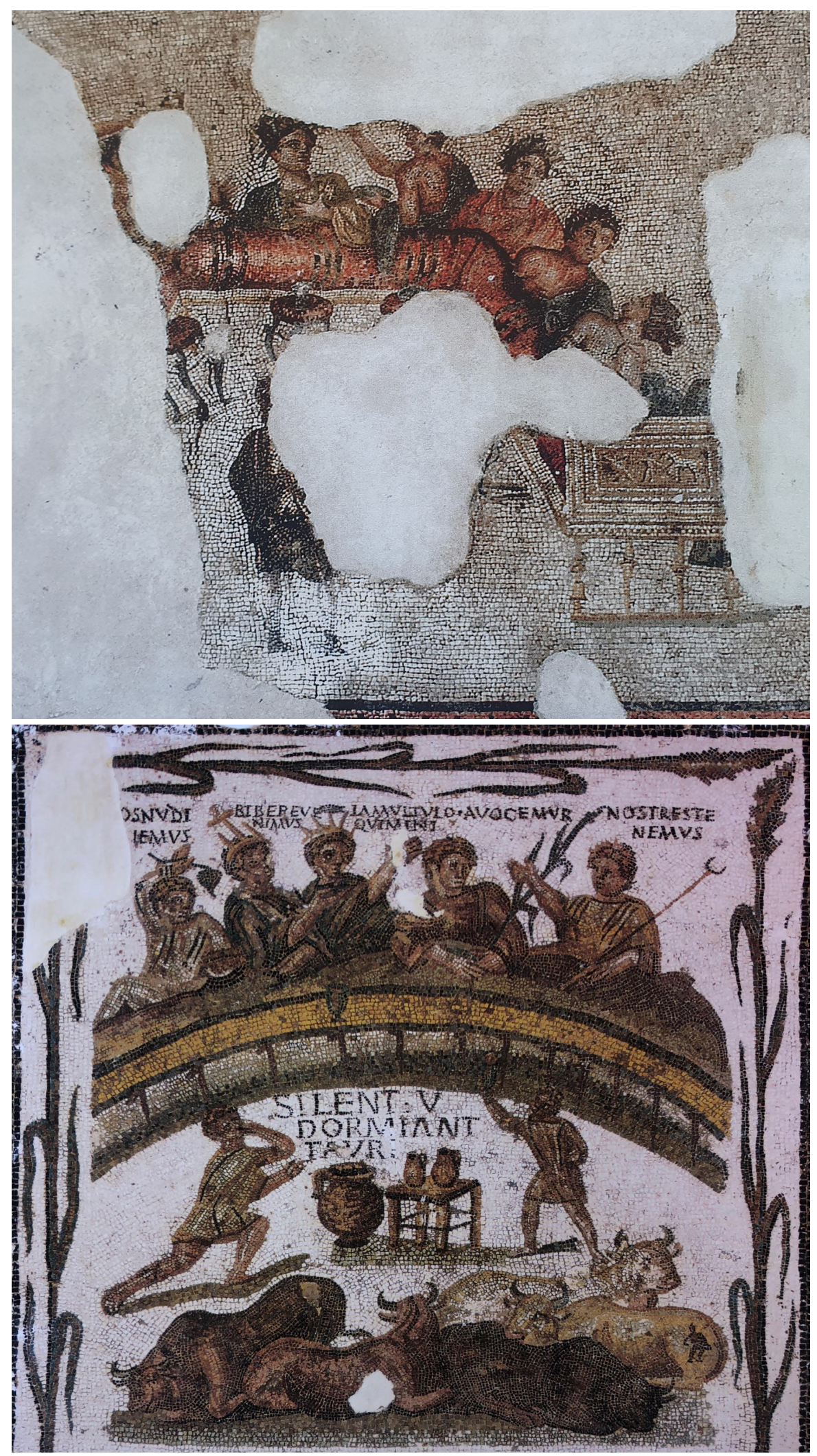

Figure 7

Fragmentary parietal mosaic

in Sant'Angelo in Formis (Campania). Photo: Robotti 2005: fig. 4.

Figure 8

Mosaic of Thysdrus.

Photo: Blanchard-Lémée et al. 1995: fig. 155. 
Regarding the success of these convivia, Pliny the Younger (Plin. epist. 3.12) ${ }^{21}$ recriminates in one of his letters to Clarus that he did not accept his invitation to an elegant dinner but instead attended another one, a dinner of luxuria, because of the served food and the Gaditanae puellae that were going to perform at the banquet.

Hence, the mosaic reflects the atmosphere that, just a century before, Pliny the Younger described in a certainly revealing paragraph from his Letters, when he expressed the displeasure caused among many educated guests by this type of commissationes, which were attended out of respect for the hosts of the banquets. These events included performances of cinaedi, buffoons and dwarves ${ }^{22}$, who would be flitting around the tables, doing - the stupidities of the dwarves (stultum a morione), - a key notion for the interpretation of the Aventine musive scene:

1. Recepi litteras tuas quibus quereris taedio tibi fuisse quamvis lautissimam cenam, quia scurrae cinaedi moriones mensis inerrabant.

Vis tu remittere aliquid ex rugis? Equidem nihil tale habeo, habentes tamen fero. Cur ergo non habeo? Quia nequaquam me ut inexspectatum festivumve delectat, si quid molle a cinaedo, petulans a scurra, stultum a morione profertur.

3. Non rationem sed stomachum tibi narro. Atque adeo quam multos putas esse, quos ea quibus ego et tu capimur et ducimur, partim ut inepta partim ut molestissima offendant! Quam multi, cum lector aut lyristes aut comoedus inductus est, calceos poscunt aut non minore cum taedio recubant, quam tu ista - sic enim appellas - prodigia perpessus es!

4. Demus igitur alienis oblectationibus veniam, ut nostris impetremus. Vale.

"I have received your letter in which you complain how offensive to you a really magnificent banquet was, owing to the fact that there were buffoons, dancers, and jesters going round from table to table. Ah! will you never relax that severe frown of yours even a little? For my own part, I do not provide any such entertainments like those, but I can put up with those who do. Why then do I not provide them myself? For this reason, that if any dancer makes a lewd movement, if a buffoon is impudent, or a jester makes a senseless fool of himself, it does not amuse me a whit, for I see no novelty or fun in it. I am not giving you a high moral reason, but am only telling you my individual taste. Yet think how many people there are who would regard with disfavour, as partly insipid and partly wearisome, the entertainments which charm and attract you and me. When a reader, or a musician, or a comic actor enters the banqueting-room, how many there are who call for their shoes or lie back on their couches just as completely bored as you were, when you endured what you describe as those monstrosities! Let us then make allowances for what pleases other people, so that we may induce others to make allowances for

21 Pliny the Younger, Letters, Volume I: Books 1-7, Loeb Classical Library, 1969. Translation by B. Radice.

22 Propertius (Prop. 4.8.37-42) already referenced a joint performance of a tibicen and crotalistria called Phillis and a dwarf in a tavern:

Lygdamus ad cyathos, uitrique aestiua supellex / et Methymnaei Graeca saliua meri. / Nile, tuus tibicen erat, crotalistria Phillis, / et facilis spargi munda sine arte rosa; / Magnus et ipse suos breuiter concretus in artus / iactabat truncas ad caua buxa manus. Lygdamus was cup-bearer, with a set of summer glassware/, and Greek wine that tasted Methymnian./ Nile, the flute-player was yours, Phyllis was castanet dancer,/ and artless elegant roses were nicely scattered; /Magnus the dwarf, himself, tiny of limb/waved his stunted hands to the boxwood flute. Cf. Propertius, Elegies, Loeb Classical Library 2006, Translation by G. P. Goold. 
us! Farewell" (Plin. epist. 9.17.1-4) ${ }^{23}$.

The participation of dwarves ${ }^{24}$ in performances, such as the one referred centuries ago by Propertius, is also documented in a passage from Lucian (Lukian. symp. 18-19) in the same context as the one described by Pliny the Younger, that of a convivium. The star of the performance is a gelotopoios, a dwarf jester named Satirion who, among other acts, contorted to the sound of music ${ }^{25}$.

Just like the cinaedi were associated with foreigners, dancers and effeminates, the figure of the prostitute-dancer, such as Quintia and Telethusa - originally described as prostitutes who dance-, was also disseminated in the Roman imaginary to a point that any woman associated with performances, such as mimes ${ }^{26}$, musicians, or dancers, was potentially considered as a prostitute (Naerebout 2009: 156-157). This derogative character was emphasised if women danced in a commissatio: they would be considered prostitutes for moral, social and cultural reasons, according to the already noted preconceived prejudices (Péché 2002: 134-135; Webb 2002: 284-285; Perea 2004: 14; Vesterinen 2007: 66-77).

Judging by the degree of specialisation, the saltatrices/crusmatistriae such as those of the Aventine mosaic would not have required much training to play the crotala, as they are easy to handle (Vesterinen 2007: 110). Just like other percussion instruments (cymbals and tympana) that due to the simplicity of their technique, easily follow the dance steps. It should be noted that the highest level of virtuosity was demanded, for both men and women, to play the tibia, and to a lesser extent for the chordophones (zither, lyre and psaltery), as well as the dance itself, which would have required a learning methodology and practice ${ }^{27}$.

In our opinion, nevertheless, the most significant aspect about the image of this commissatio (or its rehearsal) in the Aventine mosaic is undoubtedly its documentary value about society at the beginning of the third century AD. It evokes the entertainment documented in other artistic media, as well as attested by literary sources since the first century $\mathrm{BC}$ until the beginning of the second century AD. According to the aforementioned passage by Lucian, before 180 $\mathrm{AD}$, and the critical text by Clement of Alexandria, between the end of the second and the beginning of the third centuries $\mathrm{AD}$, the musive image faithfully represents the performances in one of those banquets that continued to be organized in Rome and in other urban centres of the Empire ${ }^{28}$. Thus, in book II of his Paedagogus ${ }^{29}$, on the basis that "Let revelry keep away from our rational entertainments, and foolish vigils, too, that revel in intemperance. For revelry is

23 Pliny the Younger, Letters, Volume II: Books 8-10. Panegyricus, Loeb Classical Library, 1969, Translation by B. Radice.

24 Cf. Dasen 2013: 268-272, who studies the presence of dwarves among musicians and dancers in Antiquity and their apotropaic character against the evil eye.

25 Lucian, Works, Vol. 1, Loeb Classical Library, 1913, Translation by A. M. Harmon.

26 Perea (2004: 14), interestingly notes that in her role of "merry girl", the mime was barefoot. This emphasises the cliché of a free woman, the one that has neither husband nor home, a prostitute, which would continue until Byzantine times, cf. Puchner 1983: 311-317; 2002: 304-324.

27 Vesterinen 2007: 111, he collects a series of contracts that appeared on a papyrus from Roman Egypt that mention what could be a school for flautists and dancers, a kind of academy-workshop that at the same time served as an agency to hire professionals. Cf. Alonso Fernández 2011: 443; 2015: 310.

28 About Clement's life, he travelled to the south of the Italian Peninsula and other territories of the Roman state finally settling in Alexandria, a synthesis in Alonso Venero 2013: 450-463.

29 Clemens Alexandrinus, Paedagogus, Translated by William Wilson. From Ante-Nicene Fathers, Vol. 2. Edited by Alexander Roberts, James Donaldson, and A. Cleveland Coxe (Buffalo, NY: Christian Literature Publishing Co., 1885.) Revised and edited for New Advent by Kevin Knight $<$ http://www. newadvent.org/fathers/0209.htm>. 
an inebriating pipe, the chain of an amatory bridge, that is, of sorrow. And let love, and intoxication, and senseless passions, be removed from our choir ", he predicts "For if people occupy their time with pipes, and psalteries, and choirs, and dances, and Egyptian clapping of hands, and such disorderly frivolities, they become quite immodest and intractable, beat on cymbals and drums, and make a noise on instruments of delusion; for plainly such a banquet, as seems to me, is a theater of drunkenness", emphasising on the syrinx and flute, "Let the pipe be resigned to the shepherds, and the flute to the superstitious who are engrossed in idolatry. For, in truth, such instruments are to be banished from the temperate banquet, being more suitable to beasts than men, and the more irrational portion of mankind. For we have heard of stags being charmed by the pipe, and seduced by music into the toils, when hunted by the huntsmen. And when seas are being covered, a tune is played on the flute - a nuptial song, as it were. And every improper sight and sound, to speak in a word, and every shameful sensation of licentiousness - which, in truth, is privation of sensation - must by all means be excluded; and we must be on our guard against whatever pleasure titillates eye and ear, and effeminates. For the various spells of the broken strains and plaintive numbers of the Carian muse corrupt men's morals, drawing to perturbation of mind, by the licentious and mischievous art of music ${ }^{30 "}$.

In addition to the instruments, Clement also criticises those who participate in these banquets. He disapproves women (Clem. Al. Paid. 2.11.; Conde 1986: 337-354), in particular their clothing, the custom of dyeing their hair - he seems to be describing the saltatrices of the mosaic and the potential female spectators who would emulate them - while also giggling like teenagers:

"And silly women, who dye their grey hair and anoint their locks, grow speedily greyer by the perfumes they use, which are of a drying nature. Wherefore also those that anoint themselves become drier, and the dryness makes them greyer [...] bidding farewell to embroidery of gold and Indian silks and elaborate Bombyces (silks), which is at first a worm, then from it is produced a hairy caterpillar; after which the creature suffers a new transformation into a third form which they call larva, from which a long filament is produced, as the spider's thread from the spider. For these superfluous and diaphanous materials are the proof of a weak mind, covering as they do the shame of the body with a slender veil. For luxurious clothing, which cannot conceal the shape of the body, is no more a covering. For such clothing, falling close to the body, takes its form more easily, and adhering as it were to the flesh, receives its shape, and marks out the woman's figure, so that the whole make of the body is visible to spectators, though not seeing the body itself. Dyeing of clothes is also to be rejected. For it is remote both from necessity and truth, in addition to the fact that reproach in manners spring from it."

He returns to this aspect that haunts him in the third book (Clem. Al. Paid. 3.2.), in which he states his own views that clearly show how similar pagan and Christian intellectuals are - and the critical tradition -when speaking against women:

"The woman who dyes her hair yellow, Menander the comic poet expels from the house: Now get out of this house, for no chaste. Woman ought to make her hair yellow, nor, I would add, stain her cheeks, nor paint her eyes. Unawares the poor wretches destroy their own beauty, by the introduction 
of what is spurious. At the dawn of day, mangling, racking, and plastering themselves over with certain compositions, they chill the skin, furrow the flesh with poisons, and with curiously prepared washes, thus blighting their own beau (...) These, then, who are disgusting even to the heathen poets for their fashions, how shall they not be rejected by the truth?"

In the same line, Clement continues about the behaviour of those who partake in this type of celebrations:

"For the seemly relaxation of the countenance in a harmonious manner - as of a musical instrument - is called a smile. So also is laughter on the face of well-regulated men termed. But the discordant relaxation of countenance in the case of women is called a giggle, and is meretricious laughter; in the case of men, a guffaw, and is savage and insulting laughter. A fool raises his voice in laughter, Sirach 21:20 says the Scripture; but a clever man smiles almost imperceptibly. The clever man in this case he calls wise, inasmuch as he is differently affected from the fool. But, on the other hand, one needs not be gloomy, only grave. For I certainly prefer a man to smile who has a stern countenance than the reverse; for so his laughter will be less apt to become the object of ridicule.

Smiling even requires to be made the subject of discipline. If it is at what is disgraceful, we ought to blush rather than smile, lest we seem to take pleasure in it by sympathy; if at what is painful, it is fitting to look sad rather than to seem pleased. For to do the former is a sign of rational human thought; the other infers suspicion of cruelty. We are not to laugh perpetually, for that is going beyond bounds; nor in the presence of elderly persons, or others worthy of respect, unless they indulge in pleasantry for our amusement. Nor are we to laugh before all and sundry, nor in every place, nor to everyone, nor about everything. For to children and women especially laughter is the cause of slipping into scandal and even to appear stern serves to keep those about us at their distance. For gravity can ward off the approaches of licentiousness by a mere look. All senseless people, to speak in a word, wine: Commands both to laugh luxuriously and to dance, changing effeminate manners to softness. We must consider, too, how consequently freedom of speech leads impropriety on to filthy speaking. And he uttered a word which had been better unsaid. Especially, therefore, in liquor crafty men's characters are wont to be seen through, stripped as they are of their mask through the caitiff licence of intoxication, through which reason, weighed down in the soul itself by drunkenness, is lulled to sleep, and unruly passions are roused, which overmaster the feebleness of the mind" (Clem. Al. Paid. 2.5.).

Clement confirms in his works the validity - even in his time - of customary practices transmitted long ago by the Appendix Vergiliana (App. Verg. Copa, 1-4), from the first century BC, when describing a sensual and lascivious dance in the context of Roman convivia. The dance was performed by foreign dancers, who were dressed in silk ${ }^{31}$ dresses, transparent, looking almost naked, who played a musical instrument at the same time. Apuleius, in addition, offers us an earlier story about the garments worn by the actress who played Venus in the staging of the Judgment of Paris in a Corinthian theatre that, through the eyes of

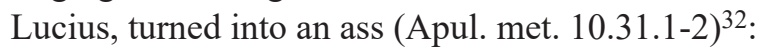

31 The movement of the flying silk from Cos or Arabia is a recurring theme in Propertius' poetry (Prop. 1.2.2; 2.1.5-6) and Horace (1.2.101-102), among others. It is very likely that the dancers were dressed in similar fabrics since they were a perfect complement to the style of their dances. Cf. Alonso Fernandez 2011: 446.

32 Apuleius, The Golden Ass (Metamorphoses), Volume II, Books 7-11, Loeb Classical Library, 1989, Translation by J. A. Hanson. 
"Her exquisite naked form was bare except for a piece of silken gauze with which she veiled her sweet charms. An inquisitive little breeze kept blowing this veil aside in wanton playfulness so that it lifted now to show her ripening bud, or now pressed madly against her, clinging tightly, smoothly delineating her voluptuous limbs. The goddess'very colouring offered interest to the eye, her body the white of heaven from which she came, her veil the cerulean blue of the sea from which she rose."

With his criticism, Clement of Alexandria documents the rejection that this type of commissationes provoked and, at the same time, the success that they continued to have in certain sectors. It is certainly revealing the excessive interest of some people to attend one of them, even cancelling a previous appointment to attend a last-minute invitation to this type of events, between the last century of the Republic and the first centuries of the Empire. Pliny the Younger discusses this with Clarus and recriminates those who would not leave the domus out of respect for the host. This diversity of situations would persist over the centuries.

It is possible that the owner of the Aventine domus, who commissioned the musive decoration of the pavements found on the grounds of Santa Sabina, would have belonged to the sector that favoured these performances, maybe trying to boast his patronage of the venationes with the preserved figurative representations (Berthier 1910: 19-20; Nogara 1910: 6-7; Blake 1940: 115-116. pl. 31, 1-4). The owner would also appear to be the organiser and host of a great banquet and in this context, of a commissatio, which would include every type of entertainment expected by his guests, although they are not represented in the stibadium. In addition to the delicacies and wine, the attendees would be delighted by the graces of a dwarf as a jester, as well as the sensual and lascivious dances of three cinaedi and two saltatrices, dressed in transparent silks, who contort to the rhythm set by the crotala, the scabellum and the tibia played by the two musicians. 


\section{Bibliography - Kaynaklar}

Alonso Fernández 2011

Alonso Fernández 2015

Alonso Venero 2013

Ashby 1914

Bailey 1980

Becatti 1961

Bélis 1988

Berthier 1910

Blake 1936

Blake 1940

Blanchard-Lemée et al. 1995

Blázquez et al. 1990

Castaldo 2014

Catalli 1992

Conde 1986

Dasen 2013

Décor I

Dunbabin 2004

Dunbabin 2016

Guidobaldi 1992

Jory 1970

King 1997

Kondoleon 1999

Lanciani 1895

Lembke 1994

Léveder Bernard - Calero 2015

Lindgren 2015

Muñoz 1914

Muñoz 1919

Muñoz 1924

Naerebout 2009
Z. Alonso, La danza en época romana: una aproximación filológica y lingüística, Unpublished PhD Thesis, Universidad Autónoma de Madrid, Madrid.

Z. Alonso, "Docta saltatrix: Body Knowledge, Culture, and Corporeal Discourse in Female Roman Dance", Phoenix 69, 3/4, 304-333.

A. M. Alonso Venero, El paganismo en la literatura apologética cristiana (ss. II-IV), Unpublished PhD Thesis, Universidad de Cantabria, Cantabria.

T. Ashby, "Drawings of Ancient Paintings in English Collections. Part I. The Eton Collecction", PBSR VII, $1-62$.

D. M. Bailey, A Catalogue of the Lamps of the British Museum 2, Roman Lamps Made in Italy, Londres.

G. Becatti, Scavi di Ostia IV, Mosaici e pavimenti marmorei, Roma.

A. Bélis, “KROUPEZA, scabellum”, BCH 102, 323-339.

J. Berthier, L'Eglise de Sainte-Sabine a Rome, Roma.

M. E. Blake, "Roman Mosaics of the Second Century in Italy”, MemAmAc 13, 67-214.

M. E. Blake, "Mosaics of the Late Empire in Rome and Vicinity”, MemAmAc 17, 81-130.

M. Blanchard-Lemée - G. Mermet - M. Ennaifer - H. Slim - L. Slim, Sols de l'Afrique romaine, Paris.

J. M. Blázquez - G. López Monteagudo - M. L. Neira Jimenez - M. P. San Nicolas Pedraz, "Pavimentos africanos con espectáculos de toros. Estudio comparativo a propósito del mosaico de Silin (Tripolitania)", AntAfr 26, 155-204.

D. Castaldo, “Presenze africane nella música di età romana”, A. Bellia (ed.), Musica, culti e riti nell’Occidente Greco, Pisa-Roma, 315-323.

F. Catalli, “L'area archeologica”, F. Catalli - M. Petrecca (eds.), Villa Pamphilj, Roma, 103-125.

E. Conde, “La mujer ideal en el „Pedagogo” de Clemente Alejandrino”, Helmantica 37, 337-354.

V. Dasen, "Des artistas différents? Nains danseurs et musiciens dans le monde hellénistique et romain", S. Emerit (dir.), Le statut du musicien dans la Méditerranée ancienne, Égypte, Mésopotamie, Grèce, Rome, El Cairo, 259-277.

C. Balmelle - M. Blanchard Lemée - J. Christophe - J.-P. Darmon - A.-M. Guimier Sorbets - H. Lavagne - R. Prudhomme - H. Stern, Le Décor géométrique de la mosaïque romaine I, Paris, 1985.

K. M. D. Dunbabin, "Problems in the Iconography of roman Mime", C. Hugoniot - F. Hurlet - S. Milanezi (eds.), Le statut de $1^{\prime}$ acteur dans $1^{‘}$ Antiquité grecque et romaine, Tours, 161-182.

K. M. D. Dunbabin, Theatre and Spectacle in Art of the Roman Empire, Ithaca-Londres.

M. P. Guidobaldi, Musica e danza, Vita e costumi dei Romani antichi 13, Roma.

E. Jory, “Associations of Actors in Rome”, Hermes 98, 224-253.

R. J. King, "Dancers in the Columbarium of the villa Doria-Pamphili”, D. Scagliarini Corlàita (ed.), I temi Figurativi nella Pittura Parietale Antica (IV sec. a.C.-IV sec. d.C.): Atti del VCI Convegno Internazionale sulla Pittura Parietale Antica, Imola, 77-80.

C. Kondoleon, "Timing Spectacles: Roman Domestic Art \& Performances" B. A. Bergmann - C. Kondoleon (eds.) The Art of Ancient Spectacle, Washington, 320-341.

R. Lanciani, "Le picturae antiquae cryptarum romanarum”, Bull. Comm. 23, 165-192.

K. Lembke, "Ein Relief aus Ariccia und seine Geschichte”, RM CI, 97-102.

G. Léveder Bernard - L. Calero ,"Las Puellae gaditanae, una coreografía con acento propio”, Anas 27-28, 107120 .

E. Lindgren, Sempronia's Song, Attitudes to Women's Music-making in Ancient Rome, Uppsala.

A. Muñoz, “Indagini sulla chiesa di Santa Sabina sull'Aventino”, Studi Romani II, 329-342.

A. Muñoz, La Basilica di Santa Sabina in Roma, Milán.

A. Muñoz, L'Eglise de Sainte Sabine a Rome, Rome.

F. G. Naerebout, "Das Reich tanzt: dance in the Roman empire and its discontents", O. Hekster - S. 
Nash 1968

Neira 2011

Nogara 1910

Péché 2002

Perea 2004

Puchner 1983

Puchner 2002

Robotti 2005

Vesterinen 2007

Wardle 1981

Webb 2002

Williams 1999

Wootton 2004
Schmidt-Hofner - C. Witschel (eds.), Ritual Dynamics and Religious Change in the Roman Empire, Leiden, 143-158.

E. Nash, Pictorial Dictionary of Ancient Rorne II, London.

L. Neira, "Sociedad e imagen en los mosaicos romanos. Desde la óptica interesada de las elites", P. Fernandez Uriel - I. Rodriguez Lopez (eds.), Iconografia y sociedad en el Mediterráneo Antiguo, Salamanca, 387-410.

B. Nogara, I mosaici antichi conservati nei palazzi pontifici del Vaticano e del Laterano, Milán.

V. Péché, "Tibicinae, fidicinae, citharistriae, psaltriae: femmes musiciennes de la comédie romaine", RBelgPhilHist 80, 1, 133-157.

S. Perea, "Extranjeras en Roma y en cualquier lugar: mujeres mimas y pantomimas, el teatro en la calle y en la fiesta de Flora", Gerión Anejos 8, 11-43.

W. Puchner, "Byzantinischer Mimos, Pantomimos und Mummenschanz im Spiegel der griechischen Patristik und ekklestiastischer Synodalverordnungen", Maske und Kothurn 29, 311-317.

W. Puchner, “Acting in Byzantine theatre: Evidence and problems”, P. Easterling - E. Hall (eds.), Greek and Roman Actors, Cambridge, 304-324.

C. Robotti, "I mosaici del Museo Campano di Capua”, CMGR IX, 1171-1173.

M. Vesterinen, Dancing and Profesional Dancers in Roman Egypt, Helsinki.

M. A. Wardle, Musical Instruments in the Roman World, Unpublished PhD Thesis, University of London, London.

R. Webb, "Female Entertainers in Late Antiquity", P. Easterling - E. Hall (eds.), Greek and Roman Actors, Cambridge, 282-303.

C. A. Williams, Roman Homosexuality, Ideologies of Masculinity in Classical Antiquity, New York.

G. E. M. Wootton, "Representations of Musicians in the Roman Mime", L. A. Beaumont - C. Barker (eds.), Festchrift in Honor of Richard Green, Sydney, 243-252. 
